\title{
Accounting
}

\section{The effect of board characteristics on the audit committee meeting frequency}

\author{
Khaled Salmen Aljaaidi $^{a^{*}}$, Raj Bahadur Sharma ${ }^{a}$ and Omar Ali Bagais ${ }^{a}$
}

${ }^{a}$ Department of Accounting, College of Business Administration, Prince Sattam bin Abdulaziz University, Saudi Arabia

\begin{tabular}{l}
\hline C H R O N I C L E \\
\hline Article history: \\
Received: November 28, 2020 \\
Received in revised format: \\
December 282020 \\
Accepted: January 20, 2021 \\
Available online: \\
January 23, 2021 \\
\hline Keywords: \\
Audit committee meeting frequency \\
Board size, board meeting \\
Saudi Arabia \\
\hline
\end{tabular}

\section{A B S T R A C T}

The focus of this study is to examine the impact of board of directors' size and meetings on the audit committee meeting frequency among energy, materials and food and beverages sectors listed on Saudi Stock Exchange (Tadawul) for the period 2015-2017. The final sample of this study consists of 198 firm-year observations. Using the Pooled OLS regression, this study finds that board meeting is positively associated with audit committee meeting frequency. Furthermore, this study fails to report an association between board size and audit committee meeting frequency. This study provides insightful evidence to policy makers on the determinants influencing the audit committee meeting frequency among manufacturing companies.

(C) 2021 by the authors; licensee Growing Science, Canada

\section{Introduction}

The primary objective of this study is to examine the relationship between the board size and board meetings with audit committee meeting frequency among manufacturing companies in Saudi Arabia. The audit committee's role of monitoring stands in the middle between the external auditor and the board of directors in ensuring effective communication, facilitating the monitoring process, and enhancing independence in the field of auditing. Committees play an important monitoring role to ensure improved financial reporting and enhancement of corporate accountability. Monitoring serves as a mediator in bridging the gap of information inconsistency between the board of directors and the external auditor. Similarly, the committee's role of monitoring also helps in promoting the independence of the auditor (Klein 2002; Birkett, 1986; Carcello et al., 2002; Carcello \& Neal, 2003; Mautz \& Neumann, 1977; Habtoor et al., 2019; Hassan et al., 2018). Basically, the supervisory role of the auditing committee involves corporate governance, auditors and auditing, and financial reporting (Wolnizer, 1995). Findings show that there is a likelihood of an effective audit committee to influence the board or management decision-making (Abbott et al., 2004; Arel, Brody \& Pany, 2006; Archambeault \& DeZoort, 2001; Owens-Jackson et al., 2009). Various reports suggest that a high level of activities is largely associated with the committee's ability to perform its duties effectively (Archambeault \& DeZoort, 2001). Additionally, the frequency of meetings is largely perceived as the better alternative measure for the level of observing activities being conducted (Greco, 2011; Collier \& Gregory, 1999; Vafeas, 1999; Laksmana, 2008; Sharma et al., 2009; Haniffa et al., 2006). Conspicuously, board meetings frequency enhances the quality of accounting information and an effective way of reducing the chances of financial fraud (Beasley, 1996; McMullen \& Raghunandam, 1996; Abbott et al., 2004; PuchetaMartínez \& De Fuentes, 2007). According to Dey (2008), an active audit committee plays a crucial role in sending a positive * Corresponding author.

E-mail address: k.aljaaidi@psau.edu.sa (K. S. Aljaaidi) 
signal regarding the quality of a company's financial and accounting information, especially when agency costs are substantial. Some reports reveal that an effective committee ensures accurate financial reporting, effective internal control, and functional risk management for individual organizations. Also, an active committee is critical in improving transparency in security markets, resulting in better protection of shareholders' interests and improving the company's book value (McMullen \& Raghunandam, 1996; Archambeault \& DeZoort, 2001; Bagais \& Aljaaidi, 2020). The recent studies suggest that the frequency of the auditing committee meeting is mainly implemented as a proxy for audit committee proficiency and observing certain financial reporting benefits for organizations with well-established audit committees (DeZoort et al., 2002; Fama \& Jensen, 1983).

There are a few studies that have investigated the determinants of audit committee meeting frequency (Menon \& Williams, 1994; Raghunandan \& Rama, 2007; Sharma et al., 2009; Greco, 2011; Al-Najjar, 2011; Thiruvadi, 2012; Maraghni \& Nekhili, 2014; Braswell, Daniels, Landis and Chang, 2012). Conversely, the extant research focuses on other developing and developed markets, and it was revealed that there is limited evidence from GCC countries. As a result, this study examines the audit committee meeting frequency in one of the top 20 countries globally and the largest economy in the Middle East and the Arab world. Additionally, previous studies recorded inconclusive and conflicting results; hence, the need to have more empirical investigations of the issues surrounding the audit committee meeting frequency. Various researchers indicated the lack of empirical evidence permitting decision-making regarding the relationships among the board meetings, the size of the board, and the frequency of audit committee meetings in Saudi Arabia. Specifically, experts postulate that the difference between the Saudi market and the global market might lead to different underlying relationships and scrutiny of the matter, resulting in more evidence to the discussion. Therefore, this study will expound on the findings of the existing research studies on the frequency of the audit committee meetings (Menon \& Williams, 1994; Raghunandan \& Rama, 2007; Sharma et al., 2009; Greco, 2011; Al-Najjar, 2011; Thiruvadi, 2012; Dellaportas et al., 2012; Maraghni and Nekhili, 2014; Braswell et al., 2012; Al-Daoud et al., 2016) by adding a new empirical evidence to the literature of corporate governance using a recent data.

The remainder of the paper is organized as follows. The next section reviews the prior studies and develops the hypotheses. The third section describes the sample, data and model of the study. Fourth section presents the results, tests and analysis. The final section concludes the study.

\section{Prior studies and hypotheses development}

\subsection{Board size and audit committee meeting frequency}

The size of board of directors plays a significant role in the monitoring and controlling of managers (Abdul Ramhan \& Mohamed Ali, 2006; Chen \& Zhou, 2007; Fama \& Jensen, 1983; Yatim et al., 2006; Lipton \& Lorsch, 1992; Aljaaidi and Hassan, 2020). Board size could either increase or decrease the frequency of audit committee meetings (Raghunandan \& Rama, 2007; Sharma et al., 2009). Vafeas (1999) argues that a larger board might be an unproductive form of governance, requiring more frequent audit committee meetings. According to Sharma et al. (2009), having more members can result in a diversity of perspectives that manifest in deeper discussions. Similarly, Greco (2011) postulates that the bigger the board size, the more the unproductive audit committee activities and meetings become. Stewart and Munro (2007) add that a larger board should focus more on promoting transparency and encouraging the diligence of the audit committee. Conspicuously, irregular and conflicting results were detected by the empirical research concerning the relationship between audit committee meeting frequency and board size. Al-Najjar (2011) and Maraghni and Nekhili (2014) reported a positive relationship between board size and audit committee meeting frequency. Conversely, an insignificant association was reported between board size and audit committee meeting frequency by several other empirical studies (Raghunandan \& Rama, 2007; Thiruvadi, 2012; Sharma et al., 2009; Dellaportas et al., 2012; Greco, 2011; Braswell et al., 2012).

Based on the conflicting results reported by the prior studies owing to the association of board size with audit committee meeting frequency, a non-directional relationship is posited, we formulate the following hypothesis:

$H_{1}$ : Ceteris paribus, board size is related to the audit committee meeting frequency.

\subsection{Board meeting and audit committee meeting frequency}

The findings further indicate that the board members who are keen on giving benefit to shareholders' meetings are likely to perform their roles diligently (Byrne, 1996; Lipton \& Lorsch, 1992). Adam (2017) and Ferreira (2011) allude that a board that can demonstrate a high level of diligence while carrying out its responsibilities of oversight is likely to improve the level of oversight of the financial reporting process (Yatim et al., 2006). The findings indicate that the most active board members based on the frequency of the meetings conducted tend to improve audit committee diligence by ensuring more frequent exchange with an audit committee member (Sharma et al. 2009; Al-Najjar 2011). The prior empirical research reported conflicting results 
on the relationship between board meetings and audit committee meeting frequency. For instance, Maraghni and Nekhili (2014), Thiruvadi (2012), Raghunandan and Rama (2007) reported a positive association relationship between board meetings and audit committee frequency. On the other hand, Braswell et al. (2012) reported a negative association between board meetings and audit committee meeting frequency.

Based on the conflicting results reported by the prior studies owing to the association of board meeting with audit committee meeting frequency, a non-directional relationship is posited, we formulate the following hypothesis:

$\mathrm{H}_{2}$ : Ceteris paribus, board meeting is related to the audit committee meeting frequency.

\section{Sample, data and model}

The population of interest comprises all manufactured companies listed on Saudi Stock Exchange (Tadawul) for the years 20152017. Our final sample comprises 198 firm-year observations. The number of the board members and meetings, total assets, debts, performance, age, and audit committee meetings were hand-collected from financial statements available on the web site of the Saudi Stock Exchange (Tadawul). Samples selected depicted in Table 1.

\section{Table 1}

Sample Selection

\begin{tabular}{lc}
\hline & Total Observations \\
\hline Total observations & 201 \\
Observations discarded (outliers, missing and incomplete data) & $(3)$ \\
Final sample & 198 \\
\hline
\end{tabular}

We control for several variables that are evidenced by prior studies to have associations with audit committee meeting frequency as a monitoring mechanism, varying based on the level of the agency costs. The first control variable is the firm size. Thiruvadi (2012) indicates that a firm's size is the most utilized variable in auditing and accounting research and serves as a proxy for complexity, political costs, and monitoring demands. He adds that large companies are likely to be multifaceted, and as such, they would require an effective audit committee to supervise and address accounting related issues (Méndez \& García, 2007, 2007; Raghunandan \& Rama, 2007; Sharma et al., 2009; Greco, 2011; Klein, 1998). The majority of the prior research confirmed a positive association between firm size and audit committee meeting frequency (Dellaportas et al., 2012; Menon and Williams, 1994; Raghunandan \& Rama, 2007; Méndez \& García, 2007; Deli and Gillan 2000; Sharma et al. 2009; Maraghni and Nekhili, 2014; Qasim, 2020; Braswell et al., 2012; Baccouche et al., 2014; Jiraporn et al., 2009). Conversely, Thiruvadi (2012) reported an insignificant association between firm size and audit committee meeting frequency.

Agency theory indicates higher leverage outcomes in lower agency due to the abuse of free cash flow by the management, which suggests a reduction in committee meeting frequency (Sharma et al., 2009; Shleifer \& Vishny, 1997; Coles et al., 2008). The risks of bankruptcy and debt-related agency costs encourage organizations to enhance the diligence of their audit committee to mitigate the risk perceived by creditors (Deli \& Gillan 2000; Sharma et al. 2009; Hahn \& Lasfer, 2007, 2016). Some empirical studies reported a negative association between leverage and audit committee meeting frequency (Dellaportas et al., 2012; Méndez \& García, 2007; Brick \& Chidambaran, 2010). On the other hand, Collier and Gregory (1999) document a marginally significant and positive association between meeting activity and firm leverage. While several other studies reported an insignificant relationship between firm leverage and audit committee meeting frequency (Maraghni \& Nekhili, 2014; Thiruvadi, 2012; Qasim, 2020; Braswell et al., 2012; Raghunandan \& Rama, 2007; Sharma et al., 2009).

Findings indicate the companies with poor performance are likely to experience errors and fraud, implying a greater need for internal auditing. Various research studies consider profitability as a control variable impacting the audit committee meeting frequency (Raghunandan \& Rama, 2007; Sharma et al., 2009; Dellaportas et al., 2012; Qasim, 2020; Adams \& Ferreira, 2007, 2009; Adams et al., 2010; Conger et al., 1998; Lin et al., 2014). While Dellaportas et al. (2012) and Qasim (2020) fail to report an association between profitability and audit committee meeting frequency. In regards to the link between audit committee meeting frequency and company's age, Evans (1987a) cites that a company's age is considered a critical factor in the growth and stability of an organization in the business environment and development. Geroski (1995) adds that a company's age has been widely utilized as a proxy for its experience over the years from the business environment, which positively impacts its performance. For a long epoch, corporate management has been acquiring a wealth of information concerning skills and capabilities (Evans, 1987b; Ramos \& Olalla, 2011).

To address the impact of board size and meeting on audit committee meeting frequency, we develop the following regression using a Pooled Ordinary least square model $O L S$ : 
where:

$\begin{array}{ll}\text { ACMEET } & =\text { Number of meetings held during the year } \\ \text { BDSIZE } & =\text { Number of directors on the board } \\ \text { BDMEET } & =\text { Number of meetings held during the year } \\ \text { LASSET } & =\log _{10} \text { of total assets } \\ \text { LEV } & =\text { Total book value of debt to total assets ratio } \\ \text { ROA } & =\text { Return on assets } \\ \text { AGE } & =\text { Number of years since the company is established } \\ \text { e } & =\text { error term. }\end{array}$

As for the measurements of the variables, Table 2 exhibits the dependent and test variables.

Table 2

Summary of the Operationalization and the Expected Sign of the Research Variables

\begin{tabular}{|c|c|c|c|}
\hline Variables & Acronym & Operationalization & $\begin{array}{l}\text { Coefficient } \\
\text { Predictions }\end{array}$ \\
\hline & & & Pooled OLS \\
\hline \multicolumn{4}{|l|}{ Dependent Variable } \\
\hline $\begin{array}{l}\text { Audit committee meeting } \\
\text { frequency }\end{array}$ & ACMEET & Number of meetings held during the year & d.v \\
\hline \multicolumn{4}{|l|}{ Hypothesized variables } \\
\hline Board size & BDSIZE & Number of directors on the board & i.v \\
\hline Board meeting & BDMEET & Number of meetings held during the year & i.v \\
\hline \multicolumn{4}{|l|}{ Control variables } \\
\hline Firm size & LASSET & $\log _{10}$ of total assets & i.v \\
\hline Firm leverage & LEV & Total book value of debt to total assets ratio & i.v \\
\hline Firm performance & $\mathrm{ROA}$ & Return on assets & i.v \\
\hline Firm age & AGE & Number of years since the company is established & i.v \\
\hline
\end{tabular}

Note: d.v - dependent variable, i.v - independent variable

\section{Results and analysis}

\subsection{Statistics and correlation}

The descriptive statistics are presented in Table 3, showing the mean, standard deviation, minimum and maximum of each variable in the sample data set.

Table 3

Descriptive statistics

\begin{tabular}{lcccc}
\hline & Mean & Minimum & Maximum & Std.Deviation \\
\hline ACMEET & 5 & 2 & 12 & 1.691 \\
BDSIZE & 8 & 5 & 2 & 15 \\
BDMEET & 5 & 19084462 & 97073302267 & 1.661 \\
LASSET & 7493387763 & 0.020 & 8.900 & 2.642 \\
LEV & 0.444 & 0.00 & 0.92 & 0.652 \\
ROA & 0.06 & 2 & 62 & 0.100 \\
AGE & 28 & & & 14.177 \\
\hline
\end{tabular}


Table 3 displays that there is a significant range of variation among the considered samples of this study. It is shown that the range of $A C M E E T$ is from 2 to 12 with an average of 5 and a standard deviation of 1.691 . The range of $B D S I Z E$ is from 5 to 15 with an average 8 and a standard deviation 1.661. The mean of BDMEET is 5 and it ranges from 2 to 22 and a standard deviation of 2.642. The mean of LASSET is 7493387763 with a maximum of 97073302267 and a minimum of 19084462 and a standard deviation of 1557623672.338 . The $L E V$ ranges from 0.020 to 8.900 and means 0.444 and a standard deviation of 0.652 . The ROA ranges from 0.00 to 0.92 with an average of 0.06 and a standard deviation of .100. As for the AGE, the mean is 28 years and it ranges from 2 to 62 and a standard deviation of 14.177.

Table 4

Correlation matrix of independent variables

\begin{tabular}{|c|c|c|c|c|c|c|}
\hline & BDSIZE & BDMEET & AGE & LASSET & LEV & ROA \\
\hline BDSIZE & 1 & & & & & \\
\hline BDMEET & -.177 & 1 & & & & \\
\hline AGE & .126 & $.168 *$ & 1 & & & \\
\hline LASSET & $.351 * *$ & $-.157 *$ & $-.195^{*}$ & 1 & & \\
\hline LEV & -.028 & .033 & .023 & .103 & 1 & \\
\hline ROA & $.161 *$ & .115 & $.244 * *$ & $-.181^{*}$ & -.074 & 1 \\
\hline
\end{tabular}

Table 4 confirms that the multicollinearity problem does not exist because the correlation matrixes among the variables do not exceed 0.90. All the variables have a correlation of equal to or less than .351 .

\subsection{Regression results}

Table 5 depicts the estimated regression coefficients for the regression model, the variance inflation factor (VIF), and the tolerance results. The highest VIF score obtained is 1.169 and the highest Tolerance score obtained is 0.977 . This confirms the non-existence of multicollinearity problem in which the VIF is lower than the threshold of 10 and Tolerance is lower than the threshold of 1 .

Table 5

Audit committee meeting frequency regression model

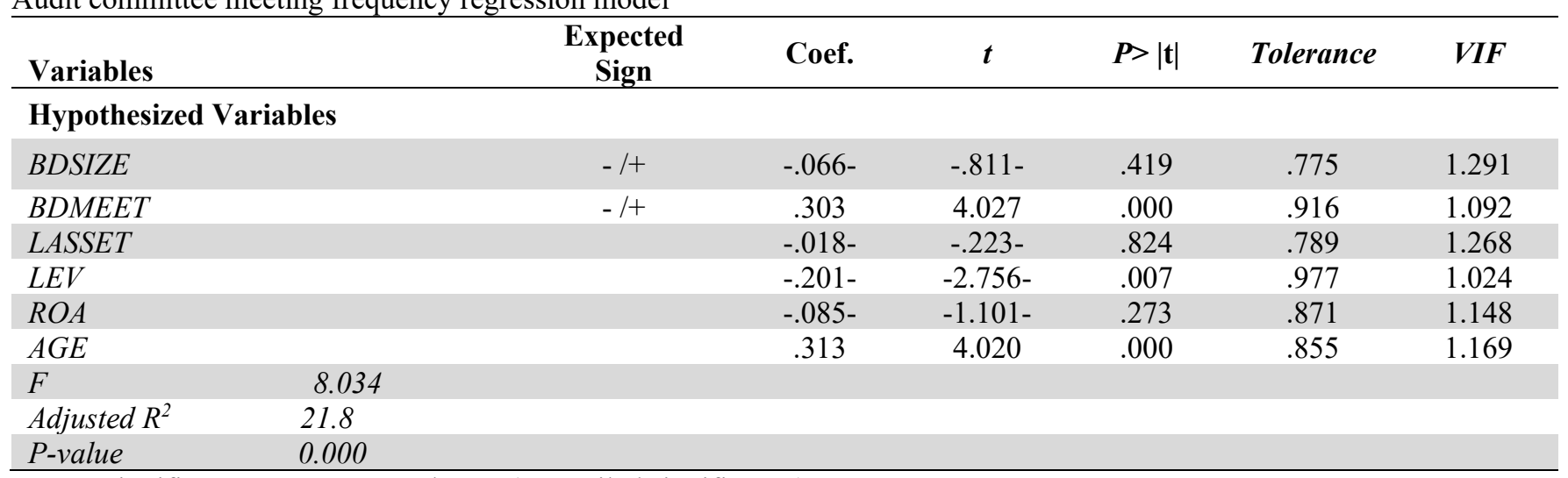

Bold $=$ significance at $1 \%, 5 \%$ and $10 \%$ (two-tailed significance)

Table 5 report the adjusted $R^{2}$ and the $F$-value for the audit committee meeting frequency model. The $F$-value for the model is statistically significant at the $1 \%$ level, indicating that the overall model can be interpreted. The adjusted $R^{2}$ is 0.218 , indicating that the model has explained $21.80 \%$ of the variance in the audit committee meeting frequency. This indicates a good fit of the audit committee meeting frequency model.

The regression results in Tables 5 show that the coefficient of BDSIZE is not significant. This result is consistent with the extant prior research (Raghunandan \& Rama, 2007; Thiruvadi, 2012; Sharma et al., 2009; Dellaportas et al., 2012; Greco, 2011; Braswell et al., 2012; Agrawal \& Knoeber, 2001). A possible explanation is that audit committee meeting frequency as an internal monitoring mechanism substitutes the board size as another internal monitoring mechanism. Thus, hypothesis $\mathrm{H}_{1}$ is accepted. 
The regression results in Table 5 presents that the coefficient of BDMEET is positive and significant $(p<0.000)$, which indicates the higher the board of directors' meetings, the more frequent the audit committee conducts meetings. This result confirms the complementary function of both board and audit committee meetings as internal corporate governance mechanisms. This result is in line with the previous studies of Maraghni and Nekhili (2014), Thiruvadi (2012), Raghunandan and Rama (2007). Therefore, hypothesis $\mathrm{H}_{2}$ is supported.

\section{Conclusions}

Our study has examined the associations of board size and board meetings with the audit committee meeting frequency among 198 manufactured Saudi listed companies on the Saudi Stock Exchange (Tadawul) for the period ranging from 2015-2017. We failed to find an association between board size and audit committee meeting frequency. This result is in line with several previous studies (Raghunandan \& Rama, 2007; Thiruvadi, 2012; Sharma et al., 2009; Dellaportas et al., 2012; Greco, 2011; Braswell et al., 2012). Consistent with Maraghni and Nekhili (2014), Thiruvadi (2012), Raghunandan and Rama (2007), we find a positive and significant relationship between board meetings and audit committee meeting frequency. This result also gives support for the complementary function of the corporate governance attributes as monitoring mechanisms.

Our study contributes to the extant literature in corporate governance in two perspectives. First, our study provides empirical evidence on the associations of two internal corporate governance mechanisms, namely; board size and board meetings, with audit committee meeting frequency in the Saudi context where there is a paucity of research in this area. Therefore, this study provides an additional empirical evidence to the literature body of corporate governance. Second, our study focuses on the manufacturing sector in Saudi Arabia which has been neglected by the prior studies as a single industry.

The findings of this study might have practical inferences for the Saudi stock market (Tdawul) that provide a new understanding regarding the extent to which an audit committee of manufacturing companies is active in a way to practice its monitoring responsibility and to protect the interests of shareholders. Similarly, the management of external auditors, bankers, and companies would also benefit from understanding the influential factors of the audit committee activities.

The study recognizes some limitations. For example, the sample of the study largely focuses on manufacturing firms. This brings the need for future research to consider incorporating other sectors such as merchandising, service, and telecommunication. Similarly, the study analyses the size of the board and meetings as test variables. Future studies could involve other determinants of corporate governance such as board of directors and the audit committee attributes, audit quality, and ownership structure. Additionally, this study was conducted in Saudi settings. Future research could replicate a similar model in different GCC countries and other Middle East countries.

\section{Acknowledgement}

This publication was supported by the Deanship of Scientific Research at Prince Sattam bin Abdulaziz University, Alkharj, Saudi Arabia.

\section{References}

Abbott, L. J., Parker, S., \& Peters, G. F. (2004). Audit committee characteristics and restatements. Auditing: A Journal of Practice \& Theory, 23(1), 69-87.

Adams, R. B., \& Ferreira, D. (2007). A theory of friendly boards. The Journal of Finance, 62(1), 217-250.

Adams, R. B., \& Ferreira, D. (2009). Women in the boardroom and their impact on governance and performance. Journal of Financial Economics, 94(2), 291-309.

Adams, R. B., Hermalin, B. E., \& Weisbach, M. S. (2010). The role of board of directors in corporate governance: A conceptual framework and survey. Journal of Economic Literature, 48, 59-108.

Agrawal, A., \& Knoeber, C. R. (2001). Do some outside directors play a political role?. The Journal of Law and Economics, 44(1), 179-198.

Al-Daoud, K. I., Saidin, S. Z., \& Abidin, S. (2016). Board meeting and firm performance: Evidence from the Amman stock exchange. Corporate Board: Role, Duties and Composition, 12(2), 6-11.

Aljaaidi, K. S., \& Hassan, W. K. (2020). Energy industry performance in Saudi Arabia: Empirical evidence. International Journal of Energy Economics and Policy, 10(4), 271-277.

Al-Najjar, B. (2012) The determinants of board meetings: evidence from categorical analysis, Journal of Applied Accounting Research, 13, 178-90.

Archambeault, D., \& DeZoort, F. (2001). Auditor opinion shopping and the audit committee: An analysis of suspicious auditor switches. International Journal of Auditing, 5(1), 33 
Arel, B., Brody, R., \& Pany, K. (2006). Findings on the effects of audit firm rotation on the audit process under varying strengths of corporate governance. Advances in Accounting, 22, 1-27.

Baccouche, S., Hadriche, M., \& Omri, A. (2014). Multiple directorships and board meeting frequency: Evidence from France. Applied Financial Economics, 24(14), 983-992.

Bagais, O., \& Aljaaidi, K. (2020). Corporate governance attributes and firm performance in Saudi Arabia. Accounting, 6(6), 923-930.

Beasley, M. S. (1996). An empirical analysis of the relation between the board of director composition and financial statement fraud. Accounting Review, 71(4), 443-465.

Birkett, B. (1980). Perceptions of the Role of Corporate Audit Committees. [Doctoral Dissertation]. The Louisiana State University.

Braswell, M., Daniels, R. B., Landis, M., \& Chang, C. C. A. (2012). Characteristics of diligent audit committees. Journal of Business \& Economics Research (JBER), 10(4), 191-206.

Brick, I. E., \& Chidambaran, N. K. (2010). Board meetings, committee structure, and firm value. Journal of Corporate Finance, 16(4), 533-553.

Byrne, J. (1996). The National Association of Corporate Directors' New Guidelines Won't Tolerate Inattentive, Passive Uninformed Board Members. Business Week, 25.

Carcello, J. V., Hermanson, D. R., Neal, T. L., \& Riley Jr, R. A. (2002). Board characteristics and audit fees. Contemporary Accounting Research, 19(3), 365-384.

Carcello, J., \& Neal, T. (2003). Audit committee characteristics and auditor dismissals following" new" going-concern reports. Accounting Review, 78(1), 95-117.

Coles, J. L., Daniel, N. D., \& Naveen, L. (2008). Boards: Does one size fit all?. Journal of Financial Economics, 87(2), 329356.

Collier, P., \& Gregory, A. (1999). Audit committee activity and agency costs. Journal of Accounting and Public Policy, 18(45), 311-332.

Conger, J. A., Finegold, D., \& Lawler, E. E. (1998). Appraising boardroom performance. Harvard Business Review, 76, 136164.

Dellaportas, S., Leung, P., Cooper, B. J., Yin, F., Gao, S., Li, W., \& Lv, H. (2012). Determinants of audit committee meeting frequency: evidence from Chinese listed companies. Managerial Auditing Journal, 27(4), 425-444.

Dey, A. (2008). Corporate governance and agency conflicts. Journal of Accounting Research, 46(5), $1143-1181$.

Evans, D. S. (1987a). The relationship between firm growth, size, and age: Estimates for 100 manufacturing industries. The Journal of Industrial Economics, 35(4), 567-581.

Evans, D. S. (1987b). Tests of alternative theories of firm growth. Journal of Political Economy, 95(4), 657-674.

Fama, E. F., \& Jensen, M. C. (1983). Separation of ownership and control. The Journal of Law and Economics, 26(2), $301-325$.

Ferreira, D., Ferreira, M. A., \& Raposo, C. C. (2011). Board structure and price informativeness. Journal of Financial Economics, 99(3), 523-545.

Greco, G. (2011). Determinants of board and audit committee meeting frequency. Managerial Auditing Journal, 26(3), 208-229

Habtoor, O., Hassan, W., \& Aljaaidi, K. (2019). The relationship between board committees and corporate risk disclosure in Saudi listed companies. International Journal of Advanced and Applied Sciences, 6(12), 41-57.

Hahn, P. D., \& Lasfer, M. (2007). Vanishing board meetings: Has governance doomed the board meeting. London: Cass Business School Research Paper.

Hahn, P. D., \& Lasfer, M. (2016). Impact of foreign directors on board meeting frequency. International Review of Financial Analysis, 46, 295-308.

Haniffa, R., Yatim, P., Kent, P., \& Clarkson, P. (2006). Governance structures, ethnicity, and audit fees of Malaysian listed firms. Managerial Auditing Journal, 21(7).

Hassan, W. K., Aljaaidi, K. S., Bin Abidin, S., \& Nasser, A. M. (2018). Internal corporate governance mechanisms and audit quality: Evidence from GCC region. International Journal of Advanced and Applied Sciences, 5(8), 72-90.

Jiraporn, P., Davidson III, W. N., DaDalt, P., \& Ning, Y. (2009). Too busy to show up? An analysis of directors' absences. The Quarterly Review of Economics and Finance, 49(3), 1159-1171.

Klein, A. (2002). Audit committee, board of director characteristics, and earnings management. Journal of Accounting and Economics, 33(3), 375-400.

Laksmana, I. (2008). Corporate board governance and voluntary disclosure of executive compensation practices. Contemporary Accounting Research, 25(4), 1147-1182.

Lin, Y. F., Yeh, Y. M. C., \& Yang, F. M. (2014). Supervisory quality of board and firm performance: a perspective of board meeting attendance. Total Quality Management \& Business Excellence, 25(3-4), 264-279.

Lipton, M., \& Lorsch, J. W. (1992). A modest proposal for improved corporate governance. The Business Lawyer, 48(1), 5977.

Maraghni, I., \& Nekhili, M. (2014). Audit committee diligence in French companies: a question of independence or competence? Comptabilité-Contrôle-Audit, 20(2), 95-124.

Mautz, R., \& Neumann, F. (1977). Corporate audit committees: Policies and practices. Cleveland, OH Ernst \& Ernst. 
McMullen, D. A., \& Raghunandan, K. (1996). Enhancing audit committee effectiveness. Journal of Accountancy, $182(2), 79$.

Méndez, C. F., \& García, R. A. (2007). The effects of ownership structure and board composition on the audit committee meeting frequency: Spanish evidence. Corporate Governance: An International Review, 15(5), 909-922.

Menon, K., \& Williams, J. D. (1994). The use of audit committees for monitoring. Journal of Accounting and Public Policy, 13(2), 121-139.

Naveen, L., Daniel, N. D., \& McConnell, J. J. (2013). The advisory role of foreign directors in US firms. Available at SSRN 2023420.

Owens-Jackson, L. A., Robinson, D., \& Shelton, S. W. (2009). The association between audit committee characteristics, the contracting process and fraudulent financial reporting. American Journal of Business, 24(1), 57-66.

Pucheta-Martínez, M. C., \& De Fuentes, C. (2007). The impact of audit committee characteristics on the enhancement of the quality of financial reporting: An empirical study in the Spanish context. Corporate Governance: An International Review, $15(6), 1394-1412$.

Qasim, A. (2020). Examining the quality of audit committee work: An empirical examination of the determinants of audit committee diligence in the UAE. Calitatea, 21(176), 109-111.

Raghunandan, K., \& Rama, D. V. (2007). Determinants of audit committee diligence. Accounting Horizons, 21 (3), $265-279$.

Ramos, R. \& Olalla, M. (2011) Board characteristics and firm performance in public founder- and nonfounder-led family businesses, Journal of Family Business Strategy, 2, 220-31.

Sharma, V., Naiker, V., \& Lee, B. (2009). Determinants of audit committee meeting frequency: Evidence from a voluntary governance system. Accounting Horizons, 23(3), 245-263.

Thiruvadi, S. (2012). Gender differences and audit committee diligence. Gender in Management: An International Journal, $27(6), 366-379$.

Vafeas, N. (1999). Board meeting frequency and firm performance. Journal of Financial Economics, 53(1), $113-142$.

Wolnizer, P. (1995). Are audit committees red herrings. Abacus, 31(1), 45-66.

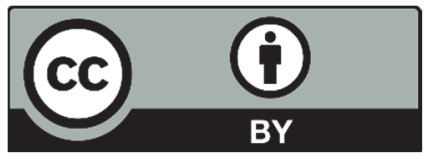

(C) 2021 by the authors; licensee Growing Science, Canada. This is an open access article distributed under the terms and conditions of the Creative Commons Attribution (CC-BY) license (http://creativecommons.org/licenses/by/4.0/). 